Viktoria S. KNIAZKOVA

DOI: $10.14746 /$ bo. 2021.1 .3

Marina Yu. KoTOVA

St. Petersburg State University

\section{The Transfer of Imagos in Translation of Nationally Oriented and Transnational Texts (As Seen in the Novels of Czech, Slovak and Russian Writers)}

Keywords: Czech, Russian, Slovak, foreign insertions, identity, realia, imago, translation, transnational fiction

\section{Abstract}

This work is an attempt to highlight the specific features of nationally oriented and transnational prose texts. Nationally oriented texts reflect history, culture and identity of one nation (e.g. prose by Solzhenitsyn and Krištúfek), transnational texts compound two or more national culture codes (e.g. prose by Brežná, Kaminer, Moníková and Škvorecký). The goal of this study is to identify specific difficulties in the process of their translation and transfer of imagos, that is stereotypical images of other identities. With the use of stylistic method, some typical ways of transmitting these imagos in literary texts are demonstrated.

\section{Introduction}

There are different amounts of national cultural code features in different types of literary texts. On the axis showing these conventional amounts, there can be found polar points with texts using a minimum of these features and texts using these features as their basis of literary expression. The first type of fiction talks about universal questions of being that do not depend on national specificities of culture. The second type considers national questions as a central theme of the narration. This type can in turn be divided into those that are characte- rized as nationally oriented, that is, rooted in one national culture, and those that are characterized as transnational, compounding two or more national culture codes.

This work is an attempt to highlight the specific features of nationally oriented and transnational prose texts. The selected material are texts by contemporary Slavic authors comprising the above-mentioned features that have not been considered in this light before. The goal of this study is to identify specific difficulties in the process of their translation and transfer of monocultural and transcultural stereotypes, or more precisely - imagos. In imagology studies, terms 'stereotype', 'cliche', 'image' and 'imago' are often used as synonymous ones, but the term 'imago' can be considered as the most neutral and precise one (Kášová 2014, 11-13). According to Lippmann (1997), the term 'stereotype' is considered as a culturally-derived picture or image in a person's mind, passed from one generation to the next and resistant to alteration. In this study, the term 'imago' is used to describe the image of another in his own, the form of a foreign one in the home one, fixation of the first one in the second one. These imagos do not reflect absolute reality, but become their own clichés and stereotypes. They are created consciously (based on a particular event or information) or subconsciously (by education, the environment) and show cultural diversity - whether close or distant. The main task of imagology is the effect and interpretation of imagos in their aesthetic, literary and cultural contexts.

\section{Transfer of Monocultural Imagos in the Literary Translation}

\section{Russian nationally oriented prose (Solzhenitsyn's Matryonin Dvor)}

The term 'nationally oriented text' with regard to fiction was introduced by Milyutina in her work Natsyonal'no orientirovannyi tekst devoted to Rasputin's prose $(2006,8)$. Nationally oriented texts were also identified and described in detail by Prokhorova and Vorontsova, but these concerned mostly didactic and educational texts (1992, 
91-92). The main characteristics of a nationally oriented text relevant for fiction are the following: a large amount of realia information and its main function being to present and understand national traditions, history and culture.

This term can be fully applied to prose by Aleksandr Solzhenitsyn (1918-2008). His language is characterized by innovations: he introduces a large amount of non-literary elements (archaisms, dialect forms, vernacular, jargon, author's own peculiar words) and he works for "the maximum possible semantic and expressive filling of the word, for its complication and transformation" (Urmanov 2000, 131). The task of the translator in this case is to study all types of content in an occasional word or phrase and reproduce them in the target language as accurately as possible (see Knyaz'kova 2007; 2009).

Let us turn to one of the aspects of the writer's literary language, namely, an epithet in the story Matryonin dvor (1959) and its translations into Slovak (Matrionina chalupa, 1964) and English (Matryona's House, 1971).

The story presents an image of the Russian village of the 1950s. The exact epithets tell the readers what kind of Russia the narrator is looking for: "Мне хотелось затесаться и затеряться в самой нутряной России - если такая где-то была, жила" (MD, 112). After exploring the meanings of the adjective нутряной (meaning "most internal") in the Dictionary of modern Russian literary language (1958, VII, 1455) and Dahl's Explanatory Dictionary of the Living Great Russian Language, on which Solzhenitsyn relied when updating the vocabulary of Russian literary language (Solzhenitsyn 1995), this word gave us a sense of something contained deep inside, in the core, and which, in addition, came from the soul and focused on the soul. This epithet says that the old Russia remained only somewhere in the hinterland and that only this Russia is spiritual and true.

Did the Slovak translator manage to convey what the author tells us with the help of the epithet нутряная Россия? In the Slovak translation - "Túžil som sa zahrabat' a stratit' v srdci Ruska - ak také niečo niekde bolo, žilo" (MCh, 5) - there is no epithet at all, only the phrase "v srdci Ruska". After checking the meaning of this expression in the dictionary (SSJ 1963, IV, 215), it appears that the use of the word srdce (the concentration of spiritual life, located in the centre) practically corresponds to the original Russian. But the conversion of the dialect lexeme into a literary one reduces its expressiveness. In addition, unlike the epithet нутряной, which illuminates the noun Россия, the expression $v$ srdci does not characterize Russia. Moreover, because the words srdce and Rusko belong to the neuter gender in Slovak, the personification of Russia in the image of a Russian woman, expressed by the verb жила and being the basis of the Russia-Matryona parallel, unfortunately does not remain. This can be achieved in Slovak by using, for example, ruská krajina.

It is important to emphasize that the English translation also uses the lexeme heart: "I just wanted to creep away and vanish in the very heartland of Russia - if there were such a place" (MH, 9).

The already presented image of the desired Russia is further deepened with the appearance of the next epithet кондовая:

А дальше целый край идет деревень: Часлицы, Овинцы, Спудни, Шевертни, Шестимирово - все поглуше, от железной дороги подале, к озерам. Ветром успокоения потянуло на меня от этих названий. Они обещали мне кондовую Россию. (MD, 114)

The epithet кондовая is also perceived in this context. According to the dictionaries mentioned above, the adjective can have direct meanings of 'strong', 'solid', 'excellent', and 'healthy' and figurative meanings of 'ancient' and 'primordial'. Here, both figurative and direct meanings are actualized, creating an image of Russia that stands on its centuries-old past and has the power to resist Soviet political and spiritual violence. The difficulty of transmitting all shades of the meaning of such an epithet to a foreign language is undeniable. Consider the Slovak translator's solution: "A potom nasleduje plno dedín: Časlice, Ovince, Šopka, Ševertne, Šestimirovo - všetky pánubohu za chrbtom, d'aleko od železnice, skôr smerom k jazerám. Dych pokoja zavial na mňa z ich názvov. Sl'ubovali mi prapôvodné Rusko" (MCh, 7). In the Slovak equivalent, the figurative meanings 'primordial' and 
to some extent 'ancient' are realized, but such shades as 'excellent' and 'healthy' are lacking.

In the English translation, two adjectives are used to compensate for the polysemy of Solzhenitsyn's epithet: "And beyond it a whole string of villages with names like Chaslitsy, Ovintsy, Spudni, Shevertni, Shestimirovo - each one more remote than the next as they stretched further and further away from the railway and nearer to the lakes. The names wafted over me like a soothing breeze. They held a promise of the true, legendary Russia" (MH, 11-12).

The culture-specific epithets considered here remain dialectical in form but realize the literary and artistic metaphor in meaning. Thanks to this, they not only serve as a faithful background to the image of the heroine and the described environment, but indirectly express the author's vision of Russia. In translation, it is possible to realize only one of the meanings, so the lost balance is restored by compensations.

\section{Slovak nationally oriented prose (Krištúfek's Dom hluchého)}

The Slovak writer Peter Krištúfek (1973-2018) was deeply interested in the national identity question - a burning issue in Slovak literature in the last three decades (Pynsent 1999; Chmel 1999). His most translated novel, Dom hluchého (2012), can be considered as a nationally oriented text.

Let us focus on the most important features of this novel and see the translators' strategies in its Czech (Düm hluchého, 2016) and English translations (The House of the Deaf Man, 2014) (see also Knyaz'kova 2019).

Krištúfek treats typical Slovak realia in untypical way - the words and expressions for culture-specific material elements are used not to add authenticity; quite the opposite, they appear as theatrical scenery:

$\mathrm{V}$ ten deň sa mal konat' Salón, takže si pani Natália nakoniec popoludní predsa len požičala personál z grófskeho kaštiel’a. Kuchára a dve služky. Konal sa zvyčajne v jej milovanej Slovenskej izbe, kde nechýbali valašky, vyrezávaný mal'ovaný nábytok na mieru, obrazy, sadrový bača s ovčiarskym psom a typický brežiansky kroj. (DH, 58)
V ten den se měl konat Salón, takže si pani Natália odpoledne nakonec půjčila personál z hraběcího zámku. Kuchaře a dvě služky. Salón se obvykle konal v její milované Slovenské jizbě, kde nechyběly valašky, na míru vyřezávaný malovaný nábytek, obrazy, sádrový bača s ovčáckým psem a typický brežanský kroj. (DHCZ, 91)

As this was the day of Natalia's regular salon, she had no choice but to borrow domestics from the manor of the local count. A cook and two maids. She usually held her salon in her beloved Slovak Room, replete with shepherds' hatchets, custom-carved folk-style wooden furniture, a plaster shepherd with a sheepdog and an example of the local costume. (HDM, 59)

The translators' strategies differ in the way they treat the Slovak realia. The lexeme kaštiel' refers to one of the types of aristocracy (mainly Hungarians) dwelling in Slovakia, which does not have an equivalent in the Czech Republic. Treating the phrase slovenská izba ('Slovak room') as a name, the Czech translator Petra Hůlová has not merely changed $i z b a$ to the neutral Czech equivalent pokoj ('room'), but offered the obsolete jizba which is phonetically close to the Slovak lexeme. Thanks to this compensation, the translator was able to show that all these pieces of traditional culture served only as decoration. The translator had to leave all the other realia in the text, because they are familiar to Czech readers as specific items of traditional Slovak culture. The English translators used the description method when translating valašky, vyrezávaný malovaný nábytok and kroj, and the generalization method when translating bača just as shepherd (see Vlakhov - Florin 1980,90-91). All these realia items are used to show the artificiality of traditional Slovak national culture.

Krištúfek was looking for true Slovakia, and an epithet he used to describe the Slovak nation is holubiči národ (DH, 387); this is rendered as národ holubiči (DHCZ, 583) in Czech and, more explicitly, as nation of peace-loving doves (HDM, 443) in English. This very phrase is frequently used by other Slovak writers, e.g. in the novel Die beste aller Welten (which is analyzed below) by the Swiss-Slovak writer Irena Brežná.

The child narrator, which is another common feature of both novels, gives the opportunity to show history from another point of view: the Second World War and the tragic events of the communist period 
are perceived more as a game. Popular Slovak children's games and rhymes, which are culture-specific terms, are also brought to our attention by Krištúfek:

A ako sa pomaly na ceste predo mnou vynára náš starý dom, $\mathrm{v}$ hlave mi ako ozvena znie detský pokrik Čik-čik, domček! Volali sme tak, ked'sme konečne dobehli do bezpečia. Bolo to zaklínadlo. Neúčinné zaklínadlo. (DH, 15)

A jak se pomalu na cestě přede mnou vynořuje náš starý dům, v hlavě mi jako ozvěna zní dětský pokřik čik-čik, domeček! Tohle jsme volali, kdy jsme konečně doběhli do bezpečí. Bylo to zaklínadlo. Neúčinné zaklínadlo. (DHCZ, 28)

As our old house gradually materializes in front of me, I hear the echo of us children shouting čik-čik, domček!, Home, home, our very own! We used to chant this when we finally reached the haven of our house. It was our private spell. A spell that didn't work. (HDM, 9)

As he becomes older, Adam, the narrator, repeats this rhyme every time he returns to the house. This popular Slovak children's rhyme was indeed made into a kind of spell by Krištúfek that he uses to refer to the bond between his heroes and the family house. The idea of the safety of the home, which this rhyme should have symbolized, turned out to be an illusion, as the house did not save the heroes from ending their lives split up and lonely.

The Czech translator uses the method of literal translation by emphasizing the realia with italics. The English translators use a borrowing in italics followed by their own equivalent rhyme in English. The next time this phrase is used in the text, the borrowing is used without any translation or explanation.

When talking about traditions or the situation in Slovakia, the author refers to it as Europe or Central Europe, which is much more than just the country. This corresponds with the ideas of another contemporary Slovak writer, Pavel Vilikovský, on Slovak national identity as a part of Central European mentality that are expressed in his novel Ever Green is ... (1989), but which are probably most fully outlined in his short story Everything I know about Central-Europeanism (with a little friendly help from Olomouc and Camus) (1996) (see Knyaz'kova 2017a).
Krištúfek's description of the narrator's son's origin turns out to be a quintessence of the author's ideas on the Slovak identity question:

V konečnom dôsledku je môj syn Bony naozaj echt pravý Slovák, pretože v jeho tele koluje česká, mad'arská, nemecká, pol'ská, židovská a nakoniec aj slovenská krv, tak to má byt'. Stredoeurópske cuvee. (DH, 34)

V konečném důsledku je můj syn Bony skutečné echt pravý Slovák, protože v jeho těle koluje česká, mad’arská, německá, polská, židovská a koneckonců i slovenská krev, tak to má být. Středoevropské cuvee. (DHCZ, 54).

Ultimately that makes my son Bony an echt Slovak because in his veins there flows Czech, Hungarian, German, Polish, Jewish and, not least, also Slovak blood. A proper Central European cuvee. (HDM, 31)

In the Slovak text, two words are emphasized by the writer in italics: echt and cuvée. Both of them are clearly of foreign origin, but are nonetheless used in Slovak. Using these foreign loanwords while characterizing the Slovak nation gives linguistic proof for the expressed literary idea.

The English translation mostly has a familiarization function, and the Czech one brings new ideas into old knowledge. The Slovak realia in the English text are mostly reproduced with the method of borrowing followed by explanation and serve as exoticisms. For a Czech reader these realia are familiar, though if read in Slovak, the whole text of the novel would have been perceived as realia. That is why Slovak borrowings in the Czech text reflect the author's intention to depict Slovak life not as it appears on the surface but what its real gist is.

\section{The Transfer of Transcultural Imagos in Literary Translations}

The prose of writers with Czech, Slovak or Russian roots who emigrated from their native countries for economic, political or other reasons and who have created their works in their mother tongue or in foreign languages can be referred to as transnational prose. A conclusion was reached in some previous research that this genre has the following literary and philosophical typological features: it is autobiographical, the national-cultural identity of the author and heroes is am- 
biguous, and it covers the problems of the integration of immigrants, the transformation of cultural memory, and the correction of stereotypes and value systems, together building a new type of national-cultural identity imago for the writer and the character of his works (Kotova 2014; 2016). The literary works, analysed in this study, always concern the "East-West" issue (Ulbrecht - Ulbrechtová 2009) as they are rooted in two cultures (Slavonic and Germanic). And through this opposition, interpreted differently by each of the authors, the imagos of both cultural identities are arised in the literary text.

From the stylistic and linguistic point of view in transnational prose, as a rule, there is intertextuality in the form of semantic allusions and foreign language insertions, which are included by the author in the text not only intentionally, as speech characteristics of the actors, but also spontaneously in the author's speech, exposing the contradictory nature of the author's system of expression, transformed under the influence of a foreign language environment. That is why their interpretation should contain intertextual analysis (Suhih 2018). These two aspects, which are the most vivid linguistic embodiments of national-cultural identities in transnational prose, must be considered in more detail. Using literary translations of transnational prose for analysis, evidence can be found of the uniqueness of a number of methods of code-switching, which have been described from other points of view by many researchers before (see e.g. Emelyanova 2019; Hostová 2017; Mareš 2003; 2012; Rusan 2016ŕ).

\section{Transfer}

\section{Czech transnational prose}

Works written in Czech or in the language of the author's environment (for example, German or English) can be referred to as Czech transnational prose. Taking into account the results of the studies of Czech identity by such researchers as Boldyreva $(2017 ; 2018)$, Čmejrková (2011), Furdal (2004), Khudyakova (2018), Korovitsyna (2011), Kreisslová (2013), Pynsent (1994; 1999), Rusan (2016b), Vlachová and Řeháková (2004) and others, we can highlight here the most typical forms of the linguistic embodiment of Czech identity using the examples of two works of transnational prose and their translations.

\section{A) English insertions in the Czech text (Škvorecký's Př́iběh inženýra lidských duši)}

English insertions in the Czech text of Škvorecký's novel Př́běh inženýra lidských duši are presented either as English inserts or as Czech graphics in accordance with Czech word-formation models, for example:

"Paní Santnerová nemůže přijít, má previous engagement" (SCzII, 152);

"Jsem živoucí stream of consciousness" (SCzII, 26);

"Byla sem atrly šokt" (from utterly shocked) (SCzI, 144);

"Nečrly sem byla enkšes védět" (from naturally and anxious) (SCzI, 154).

English insertions in the Czech text are considered by Rusan, who identified 953 examples of switching from Czech to English in her study of the novel. According to her conclusions, firstly, the bilingualism of the characters and the specifics of code-switching in this novel are directly related to the author's bilingualism $(62 \%$ of all intraphrase switches within a phrase or a simple sentence are contained in the author's speech); secondly, the code switches represent units of different levels of the English language (word, phrase, sentence, replica) in the Czech-language discourse; and thirdly, the specific function of code-switching is the creation of the effect of communication in English (stylization of speech in English) (Rusan 2016a). In the English translation of this Czech-language novel, English insertions are not highlighted at all.

\section{B) Czech insertions in the German text (Moníková's Die Fassade)}

Czech insertions in the German text of Moníková's novel Die Fassade are analyzed by Anna Boldyreva $(2017 ; 2018)$. Two types of Czech insertions are recorded in the novel. The first type was earlier 
written in German, but the author renders it in Czech, for example, Die Babička by Němcová (M, 209) (this was published in Germany in 1858 as a translation of the story Die Großmutter). This type includes Czech works of art and names, which are important for the culture of the Czech Republic, some household items that have parallels in the German language, and geographical and historical names, the meanings of which are characterized by a deeper connection with the Czech Republic, for example: Šumava (M, 139) (German Der Böhmerwald - a national forest in the mountain range that runs along the border of the Czech Republic, Germany and Austria) and Zámek Hluboká (M, 139) (German Schloss Frauenberg - a Czech castle, first mentioned in the 13th century). An important layer is the transfer of Czech names and surnames. For example, the Czech spelling of the name of the ancient Czech ruler, the wise princess who predicted the construction and greatness of Prague, is Libuše (M, 34) (cf. Libussa or Libuscha). Despite the presence of a German variant spelling of her name, in the novel it appears with the Czech spelling. The first type also includes other names that are important for Czech cultural memory, such as Jaroslav Hašek, Leoš Janáček, Jan Žižka, Svatopluk Čech, Alois Jirásek, Božena Němcová, Bedřich Smetana, Jan Amos Komenský, Karel Čapek and others.

The second type of Czech insertions in the German text includes untranslatable and untranslated realities and elements of cultural and social life, for example: laskonka (M, 138) - traditional Czech and Slovak cakes or cookies; polárka $(\mathrm{M}, 99)$ - a flavour of ice cream in the Czech Republic; deko (M, 137) - a measure of weight equal to ten grams; the names of Czech and Slovak magazines, e.g. Mladá fronta (M, 173), Lidová demokracie (M, 173), Práce (M, 173), etc.; and the names of works of art, e.g. the 1965 Czechoslovak musical Kdyby tisic klarinetů (English If a Thousand Clarinets) (M, 310).

The study of the literary translations of Škvorecký's Czech-language novel into English (SEng) and Moníková's German-language novel into Czech (MCz) leads us to a conclusion about the significant losses that occur when transferring the semantic connotations of fo- reign insertions in the originals, which are often assimilated in the translated texts (English insertions in the English translation, Czech insertions in the Czech translation) since they are not highlighted by the translators in the text.

\section{Russian transnational prose (Kaminer's Russendisko)}

Wladimir Kaminer was born in Moscow in 1967 and moved to Berlin in 1990. He published his first collection of short stories in German, Russendisko, in 2000. All the events of this autobiographical work concern the family or friends of Kaminer, thereby immersing the reader in the period of the author's youth. Kaminer writes in literary German, avoiding the use of expressive and emotional vocabulary.

Let us look at some unexpected features of the Russian translation of Russendisko. The first example is: "Die vielen Händler, die jede Woche aus Moskau nach Westberlin und zurück flogen...” $(\mathrm{K}, 9)$. In the Russian translation, a different word - челнок (shuttle) - is used, which refers to a specific profession of a person during the Soviet Union who went back and forth with goods and sold them: “Благую весть принесли челноки..." (“The good news was brought by the shuttles") (KRus, 5).

We next turn to an explication of the semantics of a German word in the Russian translation of the following passage from another story from Russendisko - Die russische Braut:

Kommt dir dein Leben langweilig vor? Bist du arbeitslos? Hast du Minderwertigkeitskomplexe oder Pickel? $(\mathrm{K}, 62)$

Если тебя угнетает зеленая тоска, хроническая безработица, прыщи или комплекс неполноценности - заведи себе русскую невесту. (KRus, 47)

[If you are depressed by green longing, chronic unemployment, acne or inferiority complex, get yourself a Russian bride.]

The translators of the Russian version use the phrase зеленая тоска (green longing), which undoubtedly brings more colour to the text and thus gives the reader the opportunity to imagine the real situa- 
tion. According to Ozhegov's explanatory dictionary, the noun тоска (longing) has a deeper connotative meaning than the lexeme скука (boredom): тоска - "душевная тревога, соединенная с грустью; унынием" ("mental anxiety, combined with sadness; despondency") (1983, 715); скука - “томление от отсутствия дела или интереса к окружающему" ("yearning from a lack of business or interest in the environment") (646).

The translator of this sentence also adds new words to the end of the phrase - "заведи себе русскую невесту" ("get yourself a Russian bride") - which are absent in the German-language original. The translator's stylistic purpose is the same: to enhance the expressiveness and concretization of the evaluation.

In many theoretical works of translation studies, it is noted that "in translation, as a rule, the true meaning of the image is lost, the hint not only does not give the reader a specific idea, but not even a general concept of the subject" (Levý 1998, 135). However, in this case, the opposite is true. The Russian translation turned out to be more expressive and emotional, and the created images are even more vivid and clear.

Thus, the hints, the understatements, the restraint of Kaminer's text are deciphered, unfolded, and retold by the translators - and this is an important feature of the Russian mentality of translators as recipients of Kaminer's work: the desire to give a comment, explanation, recommendation, or emotional assessment by actively participating and empathizing.

\section{Slovak transnational prose (Brežná's Die beste aller Welten)}

The writer and journalist Irena Brežná was born in Slovakia in 1950, and emigrated with her parents to Switzerland in 1968. The language of Brežná's works is German, but their subject matter always touches on painful aspects of life in her native Slovakia: issues of emigration and relations between peoples.
Her first novel Die beste aller Welten (2008) (Slovak Na slepačich krídlach, translated from the manuscript and published in 2007) presents the Slovak reality of the 1950s through a naive and at the same time profound description of the daily life and personal experiences of a teenage girl. The novel mentions various countries, cities, peoples, their languages, and their rulers, but does not name them directly, implying them in coded descriptions.

Es ist die Sprache unseres Brudervolkes, mit dem wir in einem Land zusammenleben. (BW, 61)

Je to reč nášho bratského národa, s ktorým žijeme v jednej krajine. (SK, 80)

Wir sind ein kleines Land mit einem großen Freund. (BW, 126)

Sme malá krajina s vel'kým priatel'om. (SK, 168)

A Slovak reader of the book can easily decipher such states as Slovakia, Czech Republic, Hungary, the Soviet Union, USA, Japan, Cuba, Ukraine, and Germany, the cities of Bratislava, Trenčín, and Budapest, and various peoples and their languages.

In this regard, there are two questions: what is this technique used for, and how is it perceived in the original text by the German-speaking reader? In the transnational novel, the author describes her life in her first homeland while utilizing the language of her second homeland. This is a common phenomenon among expatriate writers, based on a conscious detachment from what was native and now feels like a painful experience, to overcome the past in search of a new identity. Brežná herself says, "Yes, I had to write about it in German, because otherwise I would not have been able to do it at all - to pull memories out of deep cells" (Hrdličková 2012, 134-135). Thus, not only the choice of a foreign language, from the point of view of the described phenomena, but also the encrypted realia is a kind of euphemism for the author for describing the negative load of the text.

As for the perception of the original German text, the writer herself notes that the German book is more literary, more abstract, more fictional (Hrdličková 2012). In addition, the German text uses auxiliary 
lexemes to explain some insertions and realia (see also Knyaz'kova 2017b):

Als Großvater jung war, ging er wie der Held Janko in die Welt. (BW, 54) Ked' bol dedko mladý, šiel do sveta ako Janik. (SK, 71)

\section{Conclusion}

Despite the contradictions and differences between Russian prose of the middle of the 20th century and Slovak prose of the beginning of the 21 st century, there are many common typological features resulting from the national orientation of Solzhenitsyn's and Krištúfek's novels. Krištúfek was not interested in 'souvenir' Slovakia but in true Slovakia, just as Solzhenitsyn was looking for true Russia. Special lexemes serving the carriers of this national cultural code represent certain difficulties for a translator: either the inevitable losses should be compensated for, or borrowings and explanations should be used.

Both transnational and nationally oriented works of fiction are highly interested in the identity question and use different linguistic means to investigate the notion of mentality and its reflection in a text.

Nationally oriented fiction uses different marked lexemes for this purpose: archaisms, obsolete and dialect words, vernacular, jargon, and realia words. The adequacy of the translation depends on how close the target cultural code is to the original one. This means not so much the proximity of the languages but rather that of the cultural and historical experience. It is manifested in the translations of culturespecific terms, so such lexemes as children's rhymes or wordplays are easily translated from Slovak into Czech, but some historical terms that have different backgrounds are more difficult to transfer, even between such closely related languages. The situation is the same for other pairs of languages; for example, the use of dialect lexemes has a deep tradition in both Russian and Slovak literature, which means a higher degree of adequacy in their transfer than in the translation of jargon from Russian into Slovak, which has no tradition in works of fiction.
Transnational prose uses more foreign insertions and realia words. Translation strategies differ regarding the target language. If the target language coincides with the original's culture code, then the translation is perceived as the original. If the target language differs, it deals with two foreign cultural codes in one text. Such texts should thus be interpreted on the basis of intertextual analysis before being translated.

Nationally oriented texts express a collective identity (Hostová 2017, 5-6) imago; accordingly, the translator's goal is to present this collective identity imago in the fullest possible way. However, transnational works are always a clash of two or more imagos of collective identities, and the translator needs to convey the tension that arises between them.

\section{Sources shortcuts}

BW

Krištúfek P., 2012, Dom hluchého. Bratislava: Marenčin PT.

Krištúfek P., 2016, Dům hluchého, trans. P. Hůlová. Brno: Větrné mlýny.

HDM Krištúfek P., 2014, The House of the Deaf Man, trans. J. Sherwood, P. Sherwood. Cardigan: Parthian.

K Kaminer W., 2000, Russendisko. München.

KRus Kaminer W., 2008, Russendisko, trans. N. Klimenyuk, I. Kivel’. Moscow.

MCh Solženicyn A., 2003, Matrionina chalupa, trans. Z. Jesenská. Bratislava: Slovenský spisovatel'.

MCz Moníková L., 2004, Fasáda. M.N.O.P.Q. Praha: Argo.

MD Solzhenitsyn A., 1990, "Matryonin dvor.” In Rasskazy, 112-146. Moskva: Sovremennik.

M Moníková L., 1987, Die Fassade. M.N.O.P.Q. München: Carl Hanser Verlag.

MH Solzhenitsyn A., 1974, "Matryona's House”, trans. M. Glenny. In Stories and Prose Poems, 9-47. London: Penguin Books.

SCzI Šrkvorecký J., 1989, Přiběh inženýra lidských duši, I. Toronto: Sixty-Eight Publishers.

SCzII Škvorecký J., 1989, Př́běh inženýra lidských duší, II. Toronto: Sixty-Eight Publishers. 

Normal, IL: Dalkey Archive Press.

SK

Brežná I., 2010, Na slepačích krídlach. Bratislava: Aspekt.

\section{References}

B old y reva A. N., 2017, "Cheshskaya identichnost" i transnacional'nyj roman Libushe Monikovoj «Die Fassade»" ["Czech identity and the transnational novel «Facade» by Libushe Monikova"]. Mirovaya literatura na perekrestye kultur i tsivilizatsiy 3, p. 21-34.

B oldyreva A. N., 2018, "Rol' elementov russkoj kul'tury v romane Libushe Monikovoj «Die Fassade» («Fasad»)" ["The role of the elements of Russian culture in the novel «Facade»"]. Lingua Viva 26, p. 35-43.

C h e r n y s h y o v a V. I., ed., 1948-1965, Slovar' sovremennogo russkogo literaturnogo yazyka: $V 17 t$. [Dictionary of modern Russian literary language: 17 vols.]. Moskva, Leningrad: Izd-vo AN SSSR.

C h m e 1 R., 1999, "The Slovak Question in the $20^{\text {th }}$ Century." [in:] Scepticism and Hope. Sixteen Contemporary Slovak Essays, ed. by Miro Kollar, p. 59-95. Bratislava: Kalligram.

$\breve{C}$ mejrková S., 2011, Řec a konstrukce identity mluvcich (v narativním interview). [in:] Mluvená ceština: hledáni funkcního rozpětí, ed. by S. Čmejrková - J. Hoffmannová, p. 115-127. Praha: Academia.

D a h 1 V. I., 1998, Tolkovyj slovar' zhivogo velikorusskogo yazyka: V 4 t. [The Explanatory Dictionary of the Living Great Russian Language: 4 vols.]. Moskva: Citadel'.

E m e l y a n o v a Ya. B.,2019, Specifika processa pereklyucheniya kodov v perevode [The specific character of code-switching in translation]. [in:] Vestnik Sankt Peterburgskogo universiteta. Yazyk i literatura 16, No 2, p. 214-228.

F u r d a 1 A., 2004, Jazyk a národní identita. [in:] Bohemistyka, No 4, p. 241-245.

Ho s to vá I., ed., 2017, Identity and Translation Trouble. Newcastle upon Tyne: Cambridge Scholars Publishing.

H r d l i č k o vá J 2012, Der Slowakeidiskurs bei Irena Brežná und Zdenka Becker. [in:] Brünner Beiträge zur Germanistik und Nordistik 26, 1-2, p. 127-136.

K á š o v á E., 2014, Slovak Prose in German Translations after 1968 (Reception as a Way of Building the Picture of Slovak Culture and Identity) [diploma thesis]. Charles University in Prague. Faculty of Arts and Philosophy. Department of Central European Studies. Supervisor: Doc. PhDr. Rudolf Chmel. Prague.

K h u d y a k ov a E. S., 2018, Konstruirovanie identichnosti v cheshskih publichny narrativah: gruppovoe vliyanie [The Making of Identity in Czech Public Narratives: Group Infuence]. [in:] Stephanos 4, 30, p. 22-37.
Kny a ' kov a V. S., 2007, Rossiya v rasskaze A. Solzhenicyna "Matrenin dvor» $i$ v ego slovackom perevode [Russia in A. Solzhenitsyn's short story "Matrenin Dvor" and in his Slovak translation]. [in:] Slavyanskaya filologiya 9 , p. $108-119$.

Kn y a z' k o v a V. S., 2009, Recepcia diela A. Solženicyna v Rusku a na Slovensku. [in:] Slovanstvo na križovatke kultúr a civilizácií, p. 57-63. Banská Bystrica: Univerzita Mateja Bela Fakulta humanitných vied.

K n y a z' k o v a V. S., 2017a, Poisk identichnosti v tvorchestve slovackogo pisatelya P. Vilikovskogo (na materiale rasskaza "Vsyo, chto ya znayu o central'noevropeizme") [Search for identity in the work of the Slovak writer P. Vilikovsky (based on the story "All I Know about Central Europeanism")]. [in:] Filologicheskie nauki num. 3, part 2, p. 31-34.

K n y a z' k o v a V.S.,2017b, Zashifrovannye toponimy v nemeckoyazychnom romane Ireny Brezhnoj «Die beste aller Welten» $i$ ego perevode na slovackij yazyk [Encrypted place names in the German-language novel Die beste aller Welten by Irena Brezhna and its translation into the Slovak language]. [in:] Filologicheskie nauki num.10, part 2, p. 23-26.

K n y a z' k o v a V. S., 2019, Slovak Realia in the Czech Translation of the Novel The House of the Deaf Man by Peter Krištúfek in Contrast to its English Translation. [in:] Bohemistyka, No 1, p. 90-107.

K o r o v i t s in a N. V.,2011, Cheshskij chelovek vpervom desyatiletii 2000-h godov (analiz materialov CIOM IS AN ChR) [Czech Man in the First Decade of the 2000s (Analysis of Materials by the Center for the Study of Public Opinion of the Institute of Sociology of the Academy of Sciences of the Czech Republic]. Moscow.

Kotova M. Yu, ed. 2014, Segmenty identichnosti v tvorchestve zarubezhnyh slavjanskih pisatelej [Segments of Identity in the Creative Activity of Foreign Slavonic Writers]. Sankt Petersburg: Izdatelstvo Sankt-Peterburgskogo universiteta.

K o t o v a M. Yu., 2016, Specifika inokul'turnogo koda v transnacional'nom romane (na materiale prozy Mariny Levickoj) [The specificity of foreign cultural code in the transnational novel (based on the prose of Marina Lewycka)]. [in:] Filologicheskie nauki. Voprosy teorii i praktiki 11 (65), part 2, p. 106-108.

K r e i s s 1 o v á S., 2013, Konstrukce etnické identity a kolektivní paméti v biografckých vyprávénich ceských Nèmcü: na př́kladu vzpomínek Némců na Chomutovsku. Praha: Filozofická fakulta Univerzity Karlovy v Praze.

L e vý J., 1998, Uměni překladu, 2 vols. Praha: Ivo Železný.

L i p p m a n n W., 1997, Public Opinion. New York: Free Press.

M a r e š P., 2003, «Also; Nazdar!» Aspekty textové vícejazyčnosti. Praha: Karolinum. 
M a r e š P., 2012, Nejen jazykem českým. Studie o vícejazyčnosti v literatuře. Praha: Filozofická fakulta Univerzity Karlovy.

Milyutina T. A., 2006, Natsyonalno orientirovannyj tekst (cheshskij perevod povesteij Valentina Rasputina) [Nationally oriented text (Czech translation of the stories by Valentin Rasputin)]. Opole: Uniwersytet Opolski.

O z h e g o v S. I., 1983, Slovar' russkogo yazyka [Dictionary of the Russian Language]. Moskva.

P e c i a r Š., ed. 1959-1968, Slovník slovenského jazyka: I-VI diely. Bratislava: Vydavatel'stvo SAV.

P op ovi č A., 1983, Originál / Preklad. Interpretačná terminológia. Bratislava: Tatran.

Prokhorova S. M. - Voronts ov a E. G., 1992., Russkij tekst, orientirovannyj na kul'turu Belorussii [Russian text focused on the culture of Belarus]. [in:] Yazyk i kul'tura: materialy I Mezhdunarodnoj nauchnoj konf, Kiev, 9-12 June 1992, p. 90-91.

P y n s e n t R. B., 1994, Questions of Identity: Czech and Slovak Ideas of Nationality and Personality. New York: Oxford University Press.

P y n s e n t R. B., 1999, What about the Slovaks. [in:] Scepticism and Hope. Sixteen Contemporary Slovak Essays, ed. by Miro Kollar, p. 9-25. Bratislava: Kalligram.

$\mathrm{R}$ u s a $\mathrm{n}$ A.V., 2016a, Smeshenie i pereklyuchenie kodov v rechi cheshskih emigrantov [Code-mixing and code-switching in the speech of Czech emigrants (based on Josef Skvorecky's prose)]. [in:] Mezhdunarodnyj nauchno-issledovatel'skij zhurnal 6 (48), part 4, p. 56-60.

R u s a n A.V.,2016b, Anglijskie vkrapleniya v romane Jozefa Shkvoreckogo »Př́běh inženýra lidských duši» [English inclusions in the novel »The engineer of human souls« by Josef Skvorecky]. [in:] Filologicheskie nauki. Voprosy teorii i praktiki. No 7-1 (61), p. 128-130.

Ř e h á k o vá B. - V l a c h o vá K., 2004, Česká národní identita po zániku Československa a před vstupem do Evropské unie. [in:] Sociologické studie 9, p. 1-39.

Solzhenits y n A. I., 1995, Russkij slovar' yazykovogo rasshireniya. Ob"yasnenie. [Russian dictionary of language enlargement. Explanation]. Moskva: Golos.

S uh i h I. N., 2018, O granitsah intertekstualnosti: Chehovskij tekst $i$ «intertekst» [On the boundaries of intertextuality: Chekhov's text and 'intertext']. [In:] Intertekstualnyj analiz: printsipy i granitsy, ed. by A. A. Karpov - A. D. Stepanova, p. 26-35. St. Petersburg: Izdatelstvo Sankt-Peterburgskogo universiteta.
Ulbrecht S. - Ulbrechtová H., 2009, Die Ost-West-Problematik in den europäischen Kulturen und Literaturen. Ausgewählte Aspekte. Problematika Východ - Západ v evropských kulturách a literaturách. Vybrané aspekty. Slovanský ústav AV ČR/Neisse Verlag, Praha/Dresden. $800 \mathrm{~s}$.

U r m a n o v A.V., 2000, Poetika prozy Aleksandra Solzhenicyna [Poetics of prose by Aleksandr Solzhenitsyn]. Moskva: Prometej.

V 1 a k h ov S. - F 1 o r in S., 1980, Neperevodimoe v perevode [Non-translatable in translation]. Moskva: Mezhdunarodnye otnosheniya.

Z a m b o r J., 2000, Preklad ako umenie. Bratislava: Univerzita Komenského. 